\title{
Corrosion Inhibition of Mild-Steel in 0.5 M HCl using some prepared 1,2,3-Triazoles Derivatives
}

\author{
Hawraa K. Dhaef ${ }^{1, *}$, Ekhlas Q. Jasim ${ }^{2}$, Zena A. Muhajjar ${ }^{3}$ and Ashwaq A. Shanta ${ }^{1}$ \\ ${ }^{1}$ Department of Chemistry, College of Education for Pure Science, University of Basrah, Basrah 61004, Iraq \\ ${ }^{2}$ Pharmaceutical Chemistry Department, College of Pharmacy, University of Basrah, Basrah 61004, Iraq \\ ${ }^{3}$ Educational Directorate of Basrah, Ministry of Education, Basrah 61001, Iraq
}

\begin{abstract}
The Weight loss was employed to investigate the impact of triazole on mild-steel dissolution in $0.5 \mathrm{M}$ $\mathrm{HCl}$ solution. The inhibitor's inhibition efficiency was seen to increase with concentration yielding $(81.61 \%, 82.61 \%, 88.29 \%, 91.64 \%, 94.32 \%)$ of $(\mathrm{T} 9, \mathrm{~T} 8, \mathrm{~T} 6, \mathrm{~T} 4, \mathrm{~T} 1)$ at concentration $1 \times 10-4 \mathrm{M} \mathrm{HCl}$, at a temperature of $25^{\circ} \mathrm{C}$ for $240 \mathrm{~min}$. At a temperature range from $25-45^{\circ} \mathrm{C}$, we studied the temperature impact on the corrosion behavior, wherein the results demonstrated decrease in inhibition efficiency with rising in temperature to achieve $(61.7 \%, 52.26 \%, 63.1 \%, 72.11 \%, 75.77 \%)$ of $(\mathrm{T} 9, \mathrm{~T} 8, \mathrm{~T} 6, \mathrm{~T} 4$ and $\mathrm{T} 1)$ at a concentration of $1 \times 10-4 \mathrm{M}$, at a temperature $45^{\circ} \mathrm{C}$ for $240 \mathrm{~min}$. A study was also performed regarding the impact of temperature on the corrosion rate in the presence and absence of triazole. The activation energy and Kinetic parameters were calculated and discussed. Polarization curves revealed that the studied inhibitors represent a mixed - type inhibitors. Adsorption of inhibitors was found to obey Langmuir isotherm and was isotherm physisorption type.
\end{abstract}

Keywords: Corrosion, adsorption, weight loss, acid inhibition, triazole, Langmuir adsorption, kinetic parameters.

\section{Introduction}

The corrosion can be defined as a phenomenon that leads to materials deterioration via electrochemical or chemical interaction with the environment. This process could also compromise the equipment's physical and mechanical characteristics, which cast severe environmental and economic effects on all infrastructure sectors, like oil gas pipelines, roads, water and sewage systems and construction, which results in severe damage as well as threats to public safety and health ${ }^{1}$.

Numerous industrial applications employ acid solutions, such as in cleaning, elimination of located deposits, pickling and many other processes of industrial synthesis. Because of their aggressiveness characteristics, corrosion inhibitors are widely employed to limit the attack by metallic materials. The use of corrosion inhibitors needs to be estimated as per the particular parameters about the system, the kind of the acid employed, temperature solution, its concentration, presence of inorganic or dissolved organic substances and particularly the type of metallic materials employed ${ }^{2}$.

Carbon steel is known for its mechanical properties and cost-effectiveness and thus is widely employed

*Corresponding author: Hawraa K. Dhaef

E mail: haka1984d@gmail.com

DOI: http://dx.doi.org/10.13171/mjc941911101065hkd in the industry. However, low corrosion resistance is associated with this material, which results in a decrease in performance as well as useful life about the engineering products. Thus, it is crucial to apply methodologies to protect against the corrosion process, for example, corrosion inhibitor application and pre-treatments.

The corrosive process can be delayed or minimized with organic corrosion inhibitors. Their effectiveness can be chiefly associated with the adsorption on the metal surface ${ }^{3}$, which behaves as a barrier layer and decreases access to aggressive species ${ }^{4}$. As per the literature, on the metal surface, they usually get adsorbed by the action of water molecules displacement ${ }^{5}$, while improved bonding efficiency is achieved due to the presence of polar functions in the molecule's $\mathrm{S}, \mathrm{O}$ or $\mathrm{N}$ atoms, $\pi$ electrons and heterocyclic compounds ${ }^{6}$.

As 1,2,3-triazole can form a protective film on various metallic materials, it is broadly employed as a corrosion inhibitor. Also, the literature has shown that it can effectively impede steel corrosion in different types of media ${ }^{7}$. However, currently, there exist disagreements pertaining to inhibitor's toxicity for humans and the environment ${ }^{8}$. Thus, industries

Received August 31, 2019

Accepted October 2, 2019

Published November 10, 2019 
and researchers are now focusing their efforts towards mitigating this issue. Recent research studies in the corrosion field are directed towards the use of natural corrosion inhibitors that have been derived from plants ${ }^{9}$, natural herbs ${ }^{10}$, seeds ${ }^{11}$ and medicinal plants ${ }^{12}$. These are regarded as sustainable, biodegradable, cost-effective and easily available substances. Also, these do not include toxic compounds ${ }^{13}$. Numerous reports showing successful use of these substances against corrosion in various metals and acidic media ${ }^{14}$.

The current work aims at evaluating the inhibitive action of triazole, Table 1 (T9, T8, T6, T4, T1) ${ }^{15,}{ }^{16}$ in corrosion of mild steel in $0.5 \mathrm{M}$ hydrochloric acid by employing weight loss and galvanostatic polarization techniques. Furthermore, the investigation was carried out to determine the impact of temperature on the dissolution carbon mild steel and on the studied compound's inhibition efficiency.

Table 1. The structures of Triazoles (T9, T8, T6, T4, and T1).

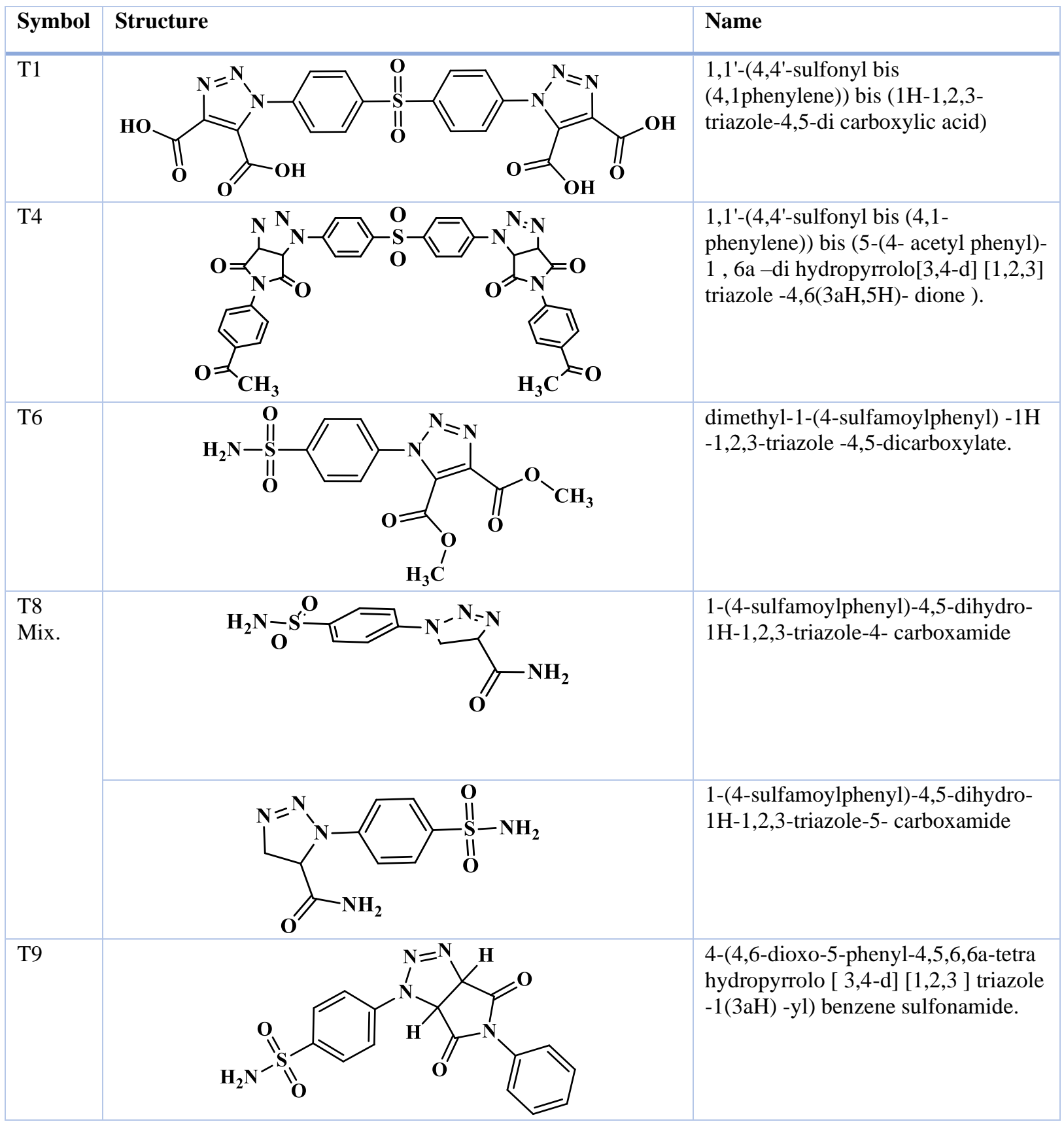

\section{Experimental method}

The mild-steel sample employed with a dimension of $3 \times 1.9 \times 0.4 \mathrm{~cm}$ for measurements of weight loss. The study employed a cylinder rod that was embedded in
Araldite with $1 \mathrm{~cm} 2$ expose e surface area. The corrosive solution was prepared by employing AR grade hydrochloric acid. For weight loss experiments, weighing of the cleaned Mild-steel coupons was done beforehand and post immersion in 
the $25 \mathrm{ml}$ test solution for $4 \mathrm{hrs}$. For the experiments, the expression of weight loss was done in grams.

\subsection{Synthesis of 1-sulfonyl 1, 2, 3-triazoles} derivatives (M1-4) ${ }^{15,16}$

A general description of the process

$\mathrm{N}$-substituted maleimide (1 mmol) was combined with $\mathrm{N}$-((4-azidophenyl) sulfonyl) acetamide (1 mmol) before the mixture was subjected to heating for a period stretching between 6 and 15 hours. The resulting precipitate was then filtered and cleansed through re-crystallization in chloroform and hexane.

\subsection{Potentiodynamic polarisation}

To study the corrosion inhibitors in $\mathrm{HCl}$ solution, measurement of potentiodynamic polarisation (Tafel) is considered crucial and is achieved via the conventional three-electrode system, while all potential were referred to SCE in this study. Tafel polarization obtained by changing the electrode potential automatically from $(+250 \mathrm{mV}$ to $-250 \mathrm{mV})$ at open circuit potential with a scan rate of $0.5 \mathrm{mV}$
S-1 to study the effect of the inhibitor on mild steel corrosion ${ }^{17-19}$. The calculation of corresponding inhibition efficiency $\left(\mathrm{I}_{\mathrm{E}} \%\right)$ ) was done based on Eq. (1) ${ }^{20}$. In this equation, Icorr and Icorr (inh) represent the corrosion current density pertaining to QS corrosion in $\mathrm{HCl}$ solution in the presence and absence of various concentrations of Inhi-ST. The linear Tafel segment of cathodic and anodic curves was extrapolated to corrosion potential to obtain the corrosion current densities (Icorr).

$$
\operatorname{IE}(100 \%)=\frac{\text { Icorr }-I \operatorname{corr}(\text { inh })}{I \operatorname{corr}} \times 100
$$

\section{Results and Discussion}

\subsection{Polarisation method}

Table 2 shows the parameters of the polarisation results (Ecorr, Icorr and $\beta \mathrm{c}$ ) for both inhibited and uninhibited solutions, after which inhibition efficiency was calculated for the MS corrosion process in the collected hydrochloric solutions.

Table 2. Electrochemical parameters for corrosion of mild steel in $0.5 \mathrm{M} \mathrm{HCl}$ in the presence of $\left(10^{-4} \mathrm{M}\right)$ concentrations of (T1, T4, T6, T8, T9) Compounds inhibitors.

\begin{tabular}{|r|r|r|r|r|r|r|}
\hline $\begin{array}{l}\text { Optimum Concentration } \\
\mathbf{M}\end{array}$ & $\mathbf{1 \times 1 0}$ & \multicolumn{1}{l|}{$\begin{array}{l}\text { Icorr. } \\
\boldsymbol{\mu} \mathbf{A} / \mathbf{c m} \mathbf{2}\end{array}$} & $\begin{array}{l}\text { Ecorr. } \\
\mathbf{m V o l t}\end{array}$ & $\boldsymbol{\beta c} \mathbf{~ m V / d m}$ & $\boldsymbol{\beta a} \mathbf{~ m V / d m}$ & $\mathbf{I}_{\mathbf{E}} \mathbf{\%}$ \\
\hline Blank & 570.65 & -342.2 & -113.1 & 95.2 & 75.57 \\
\hline $\mathbf{T 1}$ & 139.4 & -421.3 & -114.2 & 106.9 & 77.97 \\
\hline $\mathbf{T 4}$ & 125.7 & -409.5 & -91.8 & 82.8 & 79.00 \\
\hline $\mathbf{T 6}$ & 119.8 & -411.7 & -101.9 & 115.2 & 80.33 \\
\hline $\mathbf{T 8}$ & 112.2 & -416.9 & -116.2 & 88.7 & 80.88 \\
\hline $\mathbf{T 9}$ & 109.1 & -402.7 & -89.6 & 94.7 & \\
\hline
\end{tabular}

Table 3 shows comparison between E\% for some triazoles (ATM, 3) ${ }^{21,22}$ with compound T9 by using electrochemical method.

Table 3. E\% for some triazoles using electrochemical method at inhibitor con. of $10^{-4} \mathrm{M}$ in $0.5 \mathrm{M} \mathrm{HCl}$.

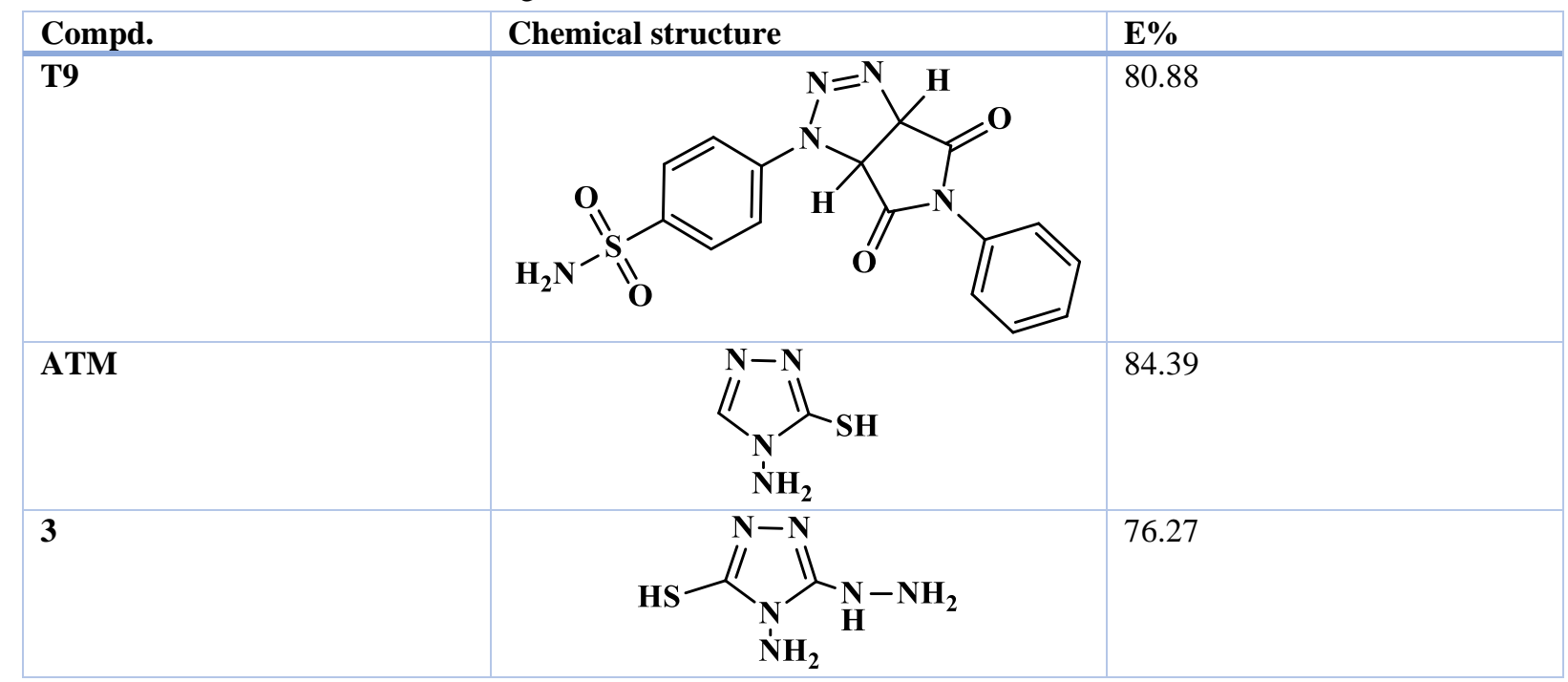


Figure 1 shows a graphical representation of the polarisation curves of MS in an acidic medium, which included $10^{-4} \mathrm{M}$ concentrations of (T9, T8, T6, $\mathrm{T} 4, \mathrm{~T} 1)$ compound at $30^{\circ} \mathrm{C}$. Both reactions, i.e. anodic and catholic, were seen to get inhibited along with the tested compounds, which resulted in retardation of the hydrogen evolution reaction as well as metal dissolution when tested compounds inhibitors were added.

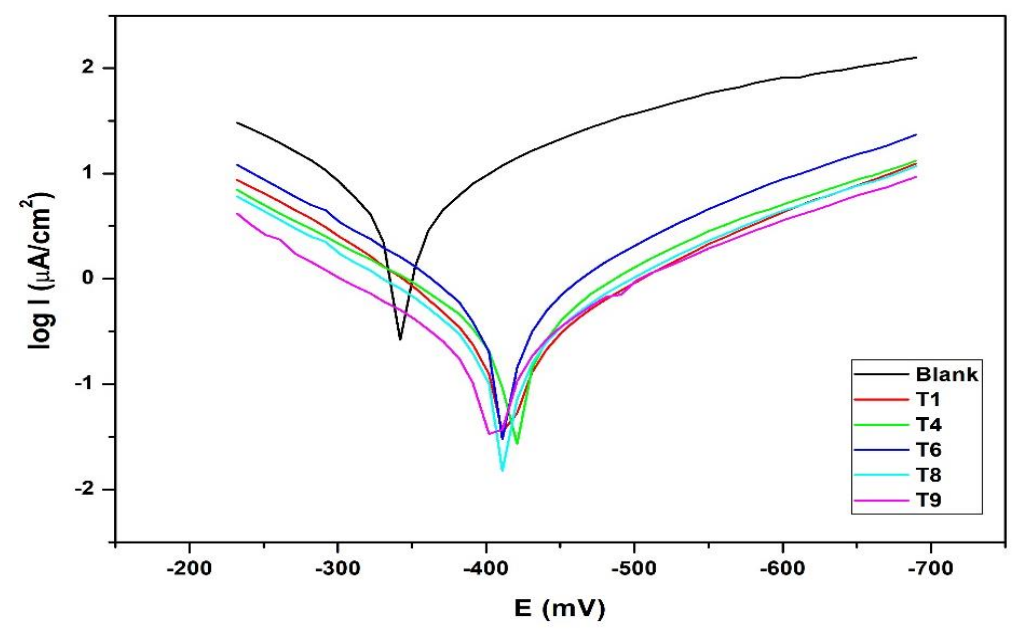

Figure 1. Tafel curves of mild steel in $0.5 \mathrm{M} \mathrm{HCl}$ solution in the absence and presence of the triazole inhibitors at $10^{-4} \mathrm{M}$ and $25^{\circ} \mathrm{C}$

\subsection{Weight Loss Measurement}

Tables 6, 7, 8, 9 and 10 (pp; 299-303) demonstrate the measurements results of the corrosion of mild steel in $0.5 \mathrm{M} \mathrm{HCl}$ in the presence and absence of various concentrations with regards to the Triazole (T9, T8, T6, T4, T1) at a temperature of $25^{\circ} \mathrm{C}$. For the percentage with regards to the inhibition efficiency \%IE as well as surface parameter coverage $\theta$, which signifies the part of the surface that was covered by inhibitor molecules, the following equation was employed for the calculation ${ }^{17}$ :

$$
\% I E=\left[1-\frac{w_{\text {add }}}{w_{\text {free }}}\right] \times 100
$$

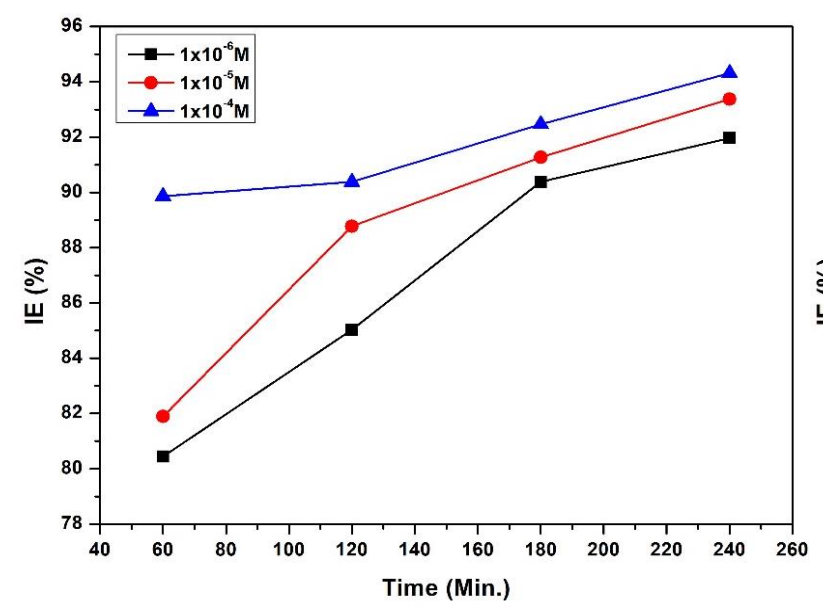

Figure 2. Variation of the Inhibition Efficiency \%IE as a Function of the Time in the Presence of Different Concentrations of $\mathrm{T} 1$ at $25^{\circ} \mathrm{C}$ in $0.5 \mathrm{M} \mathrm{HCl}$

$$
\theta=\left[1-\frac{w_{\text {add }}}{w_{\text {free }}}\right] \times W_{\text {free }}
$$

Here, $\mathrm{W}_{\text {add }}$ and $\mathrm{W}_{\text {free }}$ represented the weight losses of M-Steel in the presence and absence of inhibitors. Figures 2, 3, 4, 5 and 6 demonstrate the variation of the inhibition efficiency \%IE that has been considered as a function of time. An increase in inhibition efficiency was observed with a rise in inhibitor concentration. Calculation of the corrosion rate $\mathrm{R}_{\text {corr }}$ was done by employing the following equation $^{23}$ :

$R_{\text {corr }}=\frac{\Delta W}{s \times T}$

Where $\Delta \mathrm{W}=$ is the weight losses of metal, $\mathrm{S}=$ is the surface area $\left(\mathrm{cm}^{2}\right), \mathrm{T}=$ is the exposed time $(\mathrm{min})$.

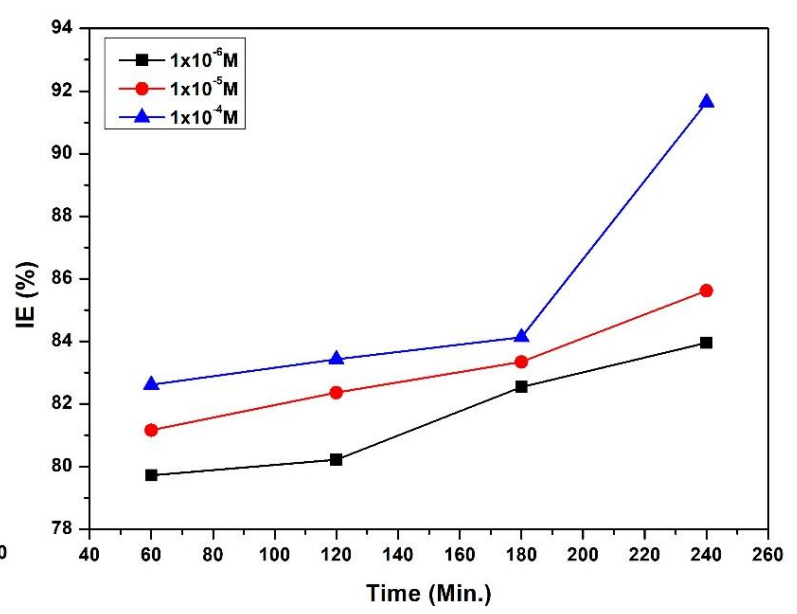

Figure 3. Variation of the Inhibition Efficiency \%IE as a Function of the Time in the Presence of Different Concentrations of $\mathrm{T} 4$ at $25^{\circ} \mathrm{C}$ in $0.5 \mathrm{M} \mathrm{HCl}$ 


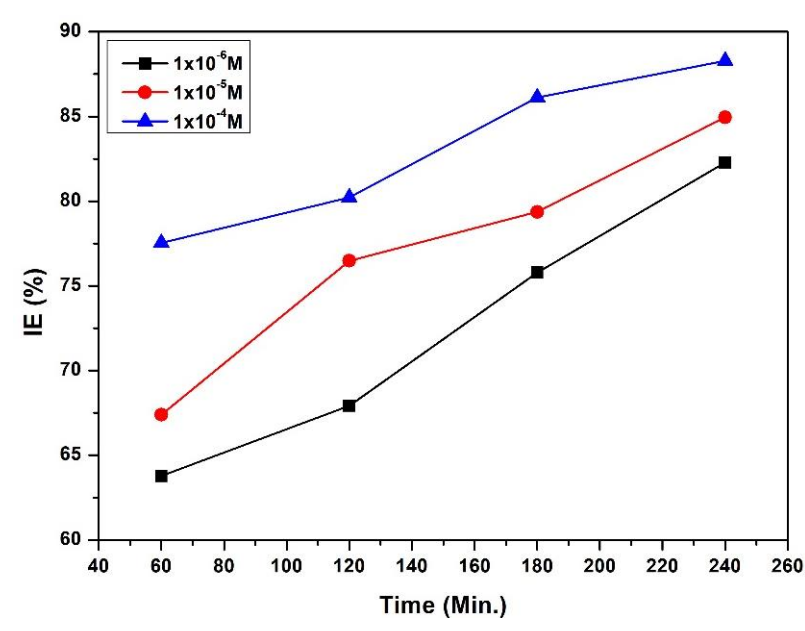

Figure 4. Variation of the Inhibition Efficiency \%IE as a Function of the Time in the Presence of Different Concentrations of $\mathrm{T} 6$ at $25^{\circ} \mathrm{C}$ in $0.5 \mathrm{M} \mathrm{HCl}$

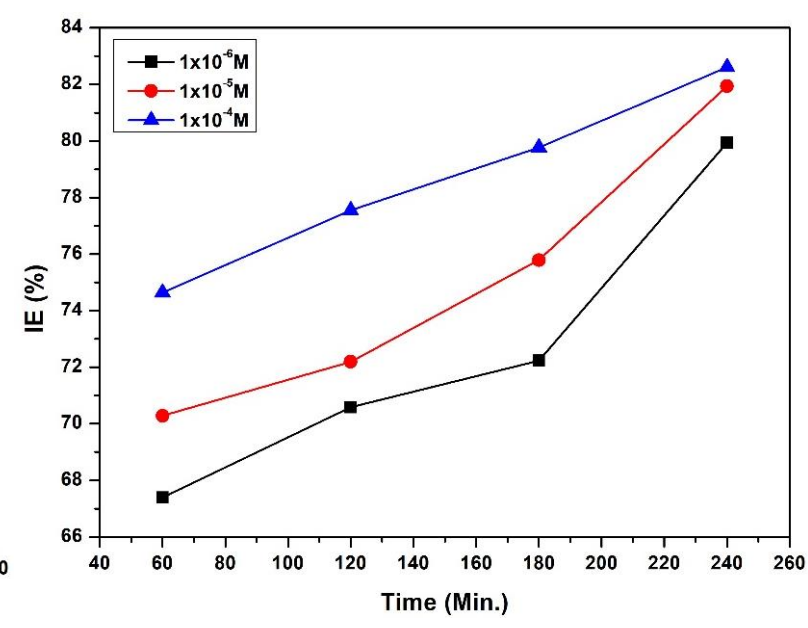

Figure 5. Variation of the Inhibition Efficiency \%IE as a Function of the Time in the Presence of Different Concentrations of $\mathrm{T} 8$ at $25^{\circ} \mathrm{C}$ in $0.5 \mathrm{M} \mathrm{HCl}$

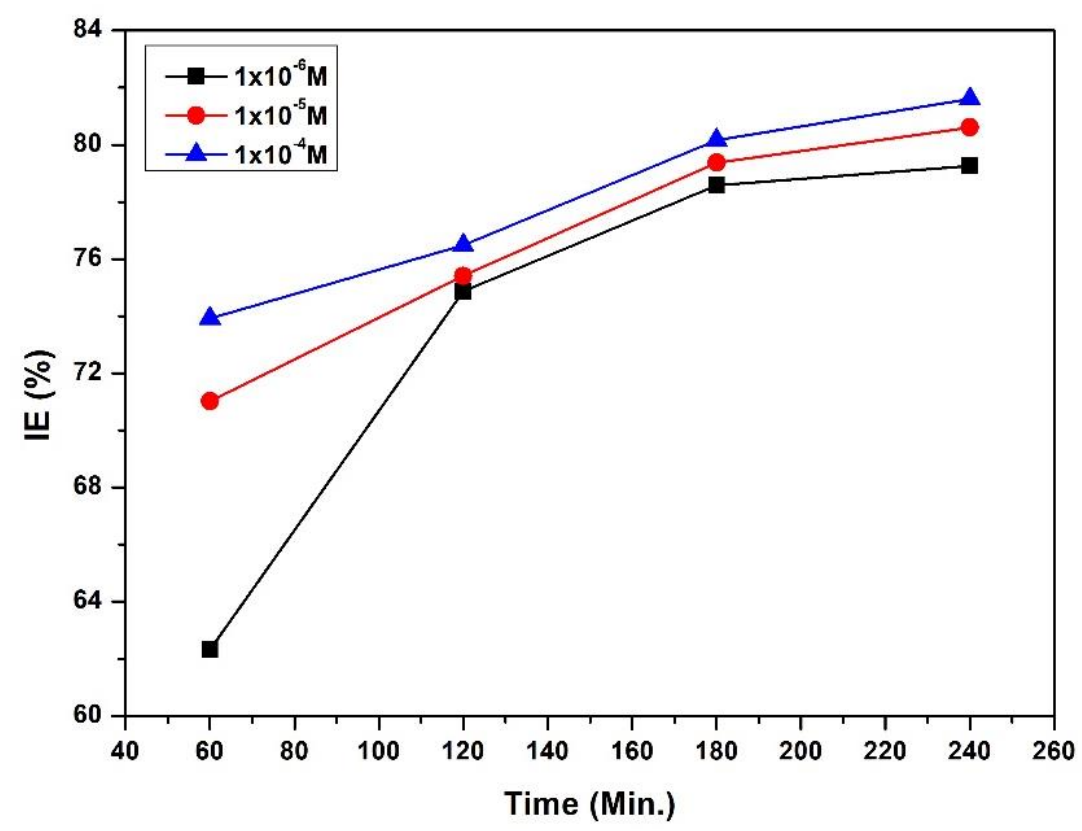

Figure 6. Variation of the Inhibition Efficiency \%IE as a Function of the Time in the Presence of Different Concentrations of (T9) at $25^{\circ} \mathrm{C}$ in $0.5 \mathrm{M} \mathrm{HCl}$

\section{1. 2. Effect of Temperature}

The temperature effect on the performance of mildsteel / acid in the presence of Triazole (T1, T4, T6, $\mathrm{T} 8$ and T9) at different concentrations was evaluated via weight-loss at a temperature range of $25-45 \mathrm{C}$ when immersed for $4 \mathrm{hrs}$. The variation of inhibition efficiency of Triazole (T1, T4, T6, T8 and T9) along with temperature was seen to reduce with the rise in temperature, which suggests a physical adsorption mechanism that is improved with rising in temperature ${ }^{24}$. Fig 7 shows the variation in inhibition efficiency \%IE with regards to the function of the temperature at a concentration of $(1 \times$ $\left.10^{-4} \mathrm{M}\right)$. The results of these measurements are depicted in Table 11 (p. 304). The temperature had an impact on the corrosion parameters of mild-steel at a concentration of $0.5 \mathrm{M} \mathrm{HCl}$. 


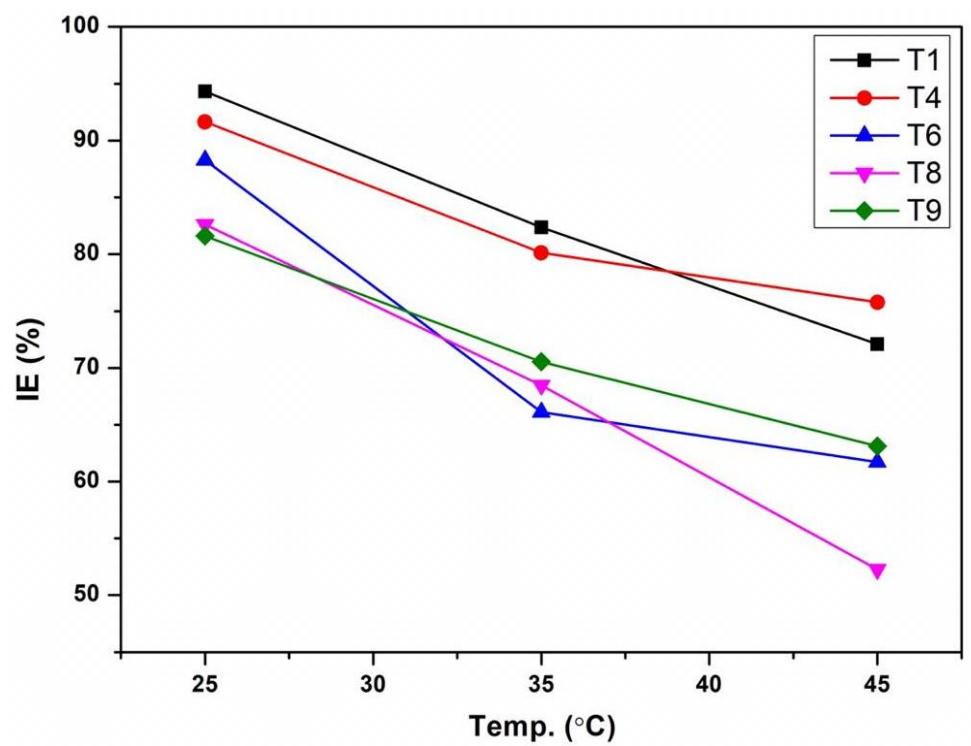

Figure 7. Variation of the Inhibition Efficiency \%IE as a Function of the Temperature in the Presence of inhibitor (T1, T4, T6, T8 and T9) in $0.5 \mathrm{M} \mathrm{HCl}$

The activation energy Ea of the corrosion process was calculated using the following equation ${ }^{25}$ :

$$
\ln (r 2 / r 1)=E a(T 2-T 1) / R(T 2 \times T 1)(5)
$$

Where:

$\mathrm{r}_{1}=$ corrosion rate at $298 \mathrm{~K}$

$\mathrm{r}_{2}=$ corrosion rate at $308 \mathrm{~K}$

$\mathrm{Ea}=$ activation energy

$\mathrm{R}=$ gas constant $\left(8.3143 \mathrm{~J} \cdot \mathrm{K}^{-1} \cdot \mathrm{mol}^{-1}\right)$

$\mathrm{T}_{1}$ and $\mathrm{T}_{2}=$ Absolute temperature $(\mathrm{K})$

The values of activation energy $\mathrm{Ea}$ has given in Table 4.

Table 4. Activation Energy for Dissolution of Mild Steel in $0.5 \mathrm{M} \mathrm{HCl}$ in the Different of (T1, T4, T6, T8 and T9) Concentration.

\begin{tabular}{|r|r|r|}
\hline Comp. & $\begin{array}{r}\text { Conc. } \\
{[\mathbf{M}]}\end{array}$ & Activation Energy KJ mol- \\
\hline HCl & 0.00 & 5.10 \\
\hline $\mathbf{T 1}$ & $1 \times 10^{-4}$ & 13.74 \\
\hline $\mathbf{T 4}$ & $1 \times 10^{-4}$ & 6.72 \\
\hline $\mathbf{T 6}$ & $1 \times 10^{-4}$ & 13.22 \\
\hline $\mathbf{T 8}$ & $1 \times 10^{-4}$ & 9.55 \\
\hline $\mathbf{T 9}$ & $1 \times 10^{-4}$ & 8.70 \\
\hline
\end{tabular}

Radovici ${ }^{26}$ categorises the inhibitors into 3 groups as per temperature effects:

1- Inhibitors exhibiting a decrease in IE along with a rise in temperature and having the value of $\mathrm{Ea}$ greater versus the uninhibited solution are indicative of physisorption.
2- Inhibitors that do not exhibit a change in IE in the absence or presence of inhibitors.

3- Inhibitors that exhibit an increase in IE along with temperature, and the value of Ea is smaller versus the inhibited solution are characteristics of chemisorption.

Furthermore, the interpreted decreases in IE value with a rise in temperature serve as an indication for a physisorption type of adsorption ${ }^{27,28}$. Thus, it can be said that via physisorption, Triazole (T6, T8, T9) gets adsorbed on the surface of mild steel.

Free energy of adsorption $\Delta \mathrm{G}$ was calculated using the following equation ${ }^{29}$.

$\Delta G=R \operatorname{Tln}[55.5 \theta l C(1-\theta)]$

Where

$\theta=$ degree of coverage on the metal surface

$\mathrm{C}=$ concentration of inhibitor $(\mathrm{T} 1, \mathrm{~T} 4, \mathrm{~T} 6, \mathrm{~T} 8$ and $\mathrm{T} 9)\left(1 \times 10^{-4} \mathrm{M}\right)$

$\mathrm{R}=$ gas constant $\left(8.3143 \mathrm{~J} \cdot \mathrm{K}^{-1} \cdot \mathrm{mol}^{-1}\right)$

$\mathrm{T}=$ Absolute temperature $(\mathrm{K})$

And for calculating the entropy $\Delta \mathrm{S}$ and enthalpy $\Delta \mathrm{H}$ apply the alternative formulation of the Arrhenius equation is the transition state equation ${ }^{30}$.

Rcorr $=\frac{R T}{N h} \exp \left[\frac{\Delta S}{R}\right] \exp \left[-\frac{\Delta H}{R T}\right]$

Where

Rcorr $=$ corrosion rate

$\mathrm{R}=$ gas constant $\left(8.3143 \mathrm{~J} \cdot \mathrm{K}^{-1} \cdot \mathrm{mol}^{-1}\right)$

$\mathrm{T}=$ temperature $(\mathrm{K})$

$\mathrm{N}=$ Avogadro 's number $\left(6.2 \times 10^{23}\right)$

$\mathrm{h}=$ plank 's constant $\left(6.62 \times 10^{-34} \mathrm{~J} . \mathrm{S}\right)$

The results of these measurements are shown in Tables 5 . 
Table 5. kinetic parameters of (T1, T4, , T6, T8, T9) $\left(1 \times 10^{-4} \mathrm{M}\right)$ on the dissolution Mild steel in $0.5 \mathrm{M} \mathrm{HCl}$.

\begin{tabular}{|c|c|c|c|c|}
\hline \multirow[t]{2}{*}{ Compounds } & \multirow[t]{2}{*}{ Tem.(K) } & \multicolumn{3}{|c|}{ Activation parameters (KJmol-1) } \\
\hline & & $\Delta \mathrm{H}$ & $-\Delta S$ & $-\Delta \mathrm{G}$ \\
\hline Blank & & 0.007275 & 0.0818 & - \\
\hline \multirow[t]{3}{*}{ T1 } & 298 & \multirow[t]{3}{*}{0.0952} & \multirow[t]{3}{*}{0.0454} & 39.732 \\
\hline & 308 & & & 37.822 \\
\hline & 318 & & & 37.482 \\
\hline \multirow[t]{3}{*}{ T4 } & 298 & \multirow[t]{3}{*}{0.0482} & \multirow[t]{3}{*}{0.1952} & 38.703 \\
\hline & 308 & & & 37.441 \\
\hline & 318 & & & 37.982 \\
\hline \multirow[t]{3}{*}{ T6 } & 298 & \multirow[t]{3}{*}{0.0794} & \multirow[t]{3}{*}{0.0921} & 37.77 \\
\hline & 308 & & & 35.588 \\
\hline & 318 & & & 36.23 \\
\hline \multirow[t]{3}{*}{ T8 } & 298 & \multirow[t]{3}{*}{0.0719} & \multirow[t]{3}{*}{0.1147} & 36.632 \\
\hline & 308 & & & 35.85 \\
\hline & 318 & & & 35.209 \\
\hline \multirow[t]{3}{*}{ T9 } & 298 & \multirow[t]{3}{*}{0.0596} & \multirow[t]{3}{*}{0.1554} & 36.463 \\
\hline & 308 & & & 36.108 \\
\hline & 318 & & & 36.389 \\
\hline
\end{tabular}

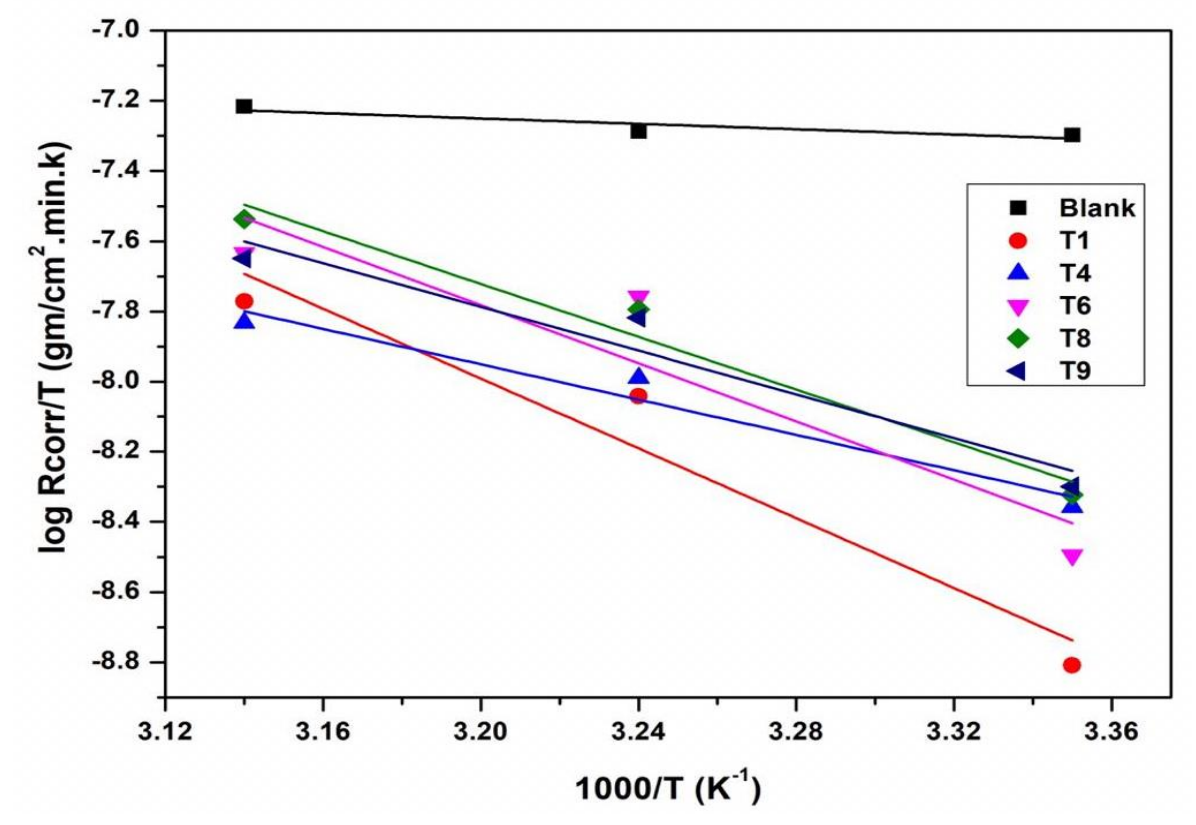

Figure 8. Arrhenius Plots $\left.\log \mathrm{R}_{\text {corr }} / \mathrm{T}\right)$ vs. $\mathrm{V}$ T for Mild-steel in Different Additives of Inhibitor (T1, T4, T6, T8, T9)

Fig. 8 shows Arrhenius Plots Log $\mathrm{R}_{\text {corr }} / \mathrm{T}$ ) vs $1 / \mathrm{T}$. Straight lines are obtained with a slop of $\mathrm{H}$ and $\Delta \mathrm{S}$ are $\Delta$ of $(\log \mathrm{R} / \mathrm{Nh}+\Delta \mathrm{S} / 2.303 \mathrm{R})$ from which the values of $\Delta$ (-calculated and listed in Table 5.

From inspection of Table 5 it is clear that the positive values of $\Delta \mathrm{H}$ reflect that the process of adsorption of the inhibitors on the Mild-steel surface

is an endothermic process. The value of $\Delta \mathrm{S}$ in the presence and absence of the inhibitors are negative.
This implies that the activation complex is the ratedetermining step representing association rather than dissociation, indicating that a decrease in disorder takes place on going from reactant to the activated complex ${ }^{27}$.

The negative values of $\Delta \mathrm{G}$ mean that the adsorption of Triazole (T1, T4, T6, T8, T9) on Mild-steel surface is a spontaneous process, and the negative values of $\Delta \mathrm{G}$ also show the strong interaction of the inhibitor molecules on to the Mild-steel surface ${ }^{31}$.

It was found that $\Delta \mathrm{G}$ increases negatively with increasing the temperature. This phenomenon once 
again indicates that the adsorption is favourable with increasing experimental temperature and dominates on the desorption of the inhibitor from the Mild-steel surface $^{32}$.

\section{2. Adsorption Isotherm}

Adsorption isotherms are crucial to understanding the inhibition mechanism of corrosion reaction. Some of the most frequently employed adsorption isotherms include Freundlich, Frumkin, Langmuir and Temkin isotherms. The one that is best fitted follows the Langmuir isotherm. Plotting $(\mathrm{C} / \theta)$ against concentration (C) yields straight lines as presented in Fig.9 On the mild-steel surface, the inhibitor Triazole (T9, T8, T6, T4, T1) gets adsorbs as per the Langmuir kind isotherm model via the relation ${ }^{33-35}$.

$C / \theta=1 / K+C$

Where

$\mathrm{K}=$ is the equilibrium constant of the adsorption process.

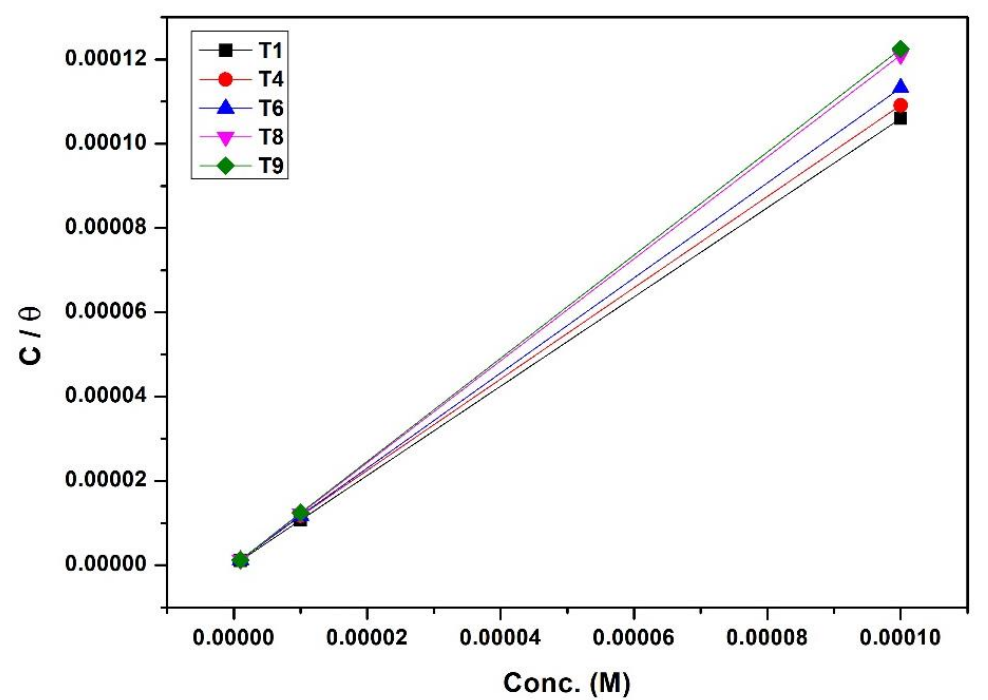

Figure 9. Langmuir Adsorption Isotherm Model for Triazole (T9, T8, T6, T4, T1) in $0.5 \mathrm{M} \mathrm{HC1}$ on the Surface of Mild- Steel

\section{Conclusions}

Can be used of Triazole compounds as inhibitors corrosion of mild steel in $0.5 \mathrm{M} \mathrm{HCl}$. There is an increase in inhibition efficiency with the rise in the concentration of Triazole compounds. The inhibition efficiency of triazole compounds decreases with temperature while there is increased activation of corrosion energy when the inhibitor is present. The inhibition corrosion of Triazole compounds (T1, T4, T6, T8 and T9) was Physisorption on the metal surface. 1,2,3-triazole derivatives obey Langmuir adsorption isotherm, and the inhibition efficiency of these compounds was in order $(\mathrm{T} 1>\mathrm{T} 4>\mathrm{T} 6>\mathrm{T} 8>$ T8> T9).

\section{References}

1- W. D. Callister Jr, Ciência e Engenharia de Materiais: Uma Introdução, $5^{\mathrm{a}}$ Edição. Rio de Janeiro: LTC 2002.

2- Z. Rouifi, M. El Faydy, H. About, F. Benhiba, H. Ramsis, M. Boudalia, H. Zarrok, R. Touir, M. El M'Rabet, H. Oudda, Electrochemical and theoretical studies of adsorption and corrosion inhibition of ethyl 5-amino-1-((8hydroxyquinolin-5-yl) methyl)-1H-1, 2, 3triazole-4-carboxylate on carbon steel in acidic solution. Journal of Materials and Environmental Sciences 2018, 9 (2), 453-465.

3- O. Adeyemi, Effect of temperature and concentration on the protective action of 5membered heterocyclics in the acid corrosion of alpha-brass. Bull. Electrochem. 2005, 21 (8), 363-366.

4- E. Oguize; Okolue, B.; Ogukwe, C.; Onuchukwu, A., Studies on the inhibitive action of methylene blue dye on aluminium corrosion in $\mathrm{KOH}$ solution. Journal of Corrosion Science and Technology 2004, 1 (1), 88-91.

5- E. Rodriguez-Clemente, J. Gonzalez-Rodriguez, M. Valladares-Cisneros, Allium sativum as corrosion inhibitor for carbon steel in sulfuric acid. Int. J. Electrochem. Sci 2014, 9, 5924-5936.

6- D. B. Hmamou, M. Aouad, R. Salghi, A. Zarrouk, M. Assouag, O. Benali, M. Messali, H. Zarrok, B. Hammouti, Inhibition of C38 steel corrosion in hydrochloric acid solution by 4, 5-Diphenyl1H-Imidazole-2-Thiol: Gravimetric and temperature effects treatments. Journal of Chemical and Pharmaceutical Research 2012, 4 (7), 3498-3504.

7- K. Khaled, Molecular simulation, quantum chemical calculations and electrochemical studies for inhibition of mild steel by triazoles. Electrochim. Acta 2008, 53 (9), 3484-3492. 
8- D. Lake, Approaching environmental acceptability in cooling water corrosion inhibition. Corrosion Prevention \& Control 1988, 35 (4), 113-115.

9- F. A. Ayeni, S. Alawode, D. Joseph, P. Sukop, V. Olawuyi, T. E. Alonge, O. O. Alabi, O. Oluwabunmi, F. I. Alo, Investigation of Sida acuta (wire weed) plant extract as corrosion inhibitor for aluminium-copper-magnesium alloy in acidic medium. Journal of Minerals and Materials Characterization and Engineering 2014, 2 (04), 286.

10-B. Zerga, M. Sfaira, Z. Rais, M. E. Touhami, M. Taleb, B. Hammouti, B. Imelouane, A. Elbachiri, Lavender oil as an eco-friendly inhibitor for mild steel in $1 \mathrm{M} \mathrm{HCl}$. Matériaux \& techniques $\mathbf{2 0 0 9}$, 97 (5), 297-305.

11-A. Singh, M. Quraishi, The extract of Jamun (Syzygiumcumini) seed as a green corrosion inhibitor for acid media. Res. Chem. Internet. 2015, 41 (5), 2901-2914.

12-F. Fadel, D. Ben Hmamou, R. Salghi, B. Chebli, O. Benali, A. Zarrouk, E. Ebenso, A. Chakir, B. Hammouti, Antifungal activity and anti-corrosion inhibition of Origanum compactum extracts. Int $J$ Electrochem Sci 2013, 8, 11019-11032.

13-C. Loto, The effect of bitter leaf extracts on corrosion of mild steel in $0.5 \mathrm{M} \mathrm{HCl}$ and $\mathrm{H} 2 \mathrm{SO} 4$ solutions. Nigeria corrosion Journal international 1998, 1, 19-20.

14-A. Alsabagh, M. Migahed, M. Abdelraouf, E. Khamis, Utilization of green tea as an environmentally friendly corrosion inhibitor for carbon steel in acidic media. Int. J. Electrochem. Sci 2015, 10 (2), 1855-1872.

15-F. A. Almashal, M. Khalaf, 1, 3-Dipolar Cycloaddition for 4-Azidobenzene Sulfonamide with Acetylenic and Olefinic Compounds. basrah journal of science 2014, 32 (1C eng), 49-69.

16-M. K. Almayahi, Synthesis Characterization and Biological activity study of some new Bis and Mono 1,2,3-Triazole and Triazoline compounds. University of Basrah, 2012.

17-J. Li, B. Hurley, R. Buchheit, The Effect of $\mathrm{CeCl} 3$ as an Inhibitor on the Localized Corrosion of AA2024-T3 as a Function of Temperature. $J$. Electrochem. Soc. 2016, 163 (14), C845-C852.

18-A. Yousefi, S. Javadian, J. Neshati, A new approach to studying the synergistic inhibition effect of cationic and anionic surfactants on the corrosion of mild steel in $\mathrm{HCl}$ solution. Industrial \& Engineering Chemistry Research 2014, 53 (13), 5475-5489.

19-Q. Q. Liao, Z. W. Yue, D. Yang, Z. H. Wang, Z. H. Li, H. H. Ge, Y. J. Li, Self-assembled monolayer of ammonium pyrrolidine dithiocarbamate on copper detected using electrochemical methods, surface-enhanced Raman scattering and quantum chemistry calculations. Thin Solid Films 2011, 519 (19), 6492-6498.
20-1. S. Nordin Ben, I. Raissouni, K. Draoui, A. A. Aghzzaf, A. Charaka, B. Aznag, F. Chaouket and D. Buchta, "Calcite, the main corrosion inhibitor contained in the raw clay (Rhassoul) of brass in $3 \% \mathrm{NaCl}$ medium", Mediterranean Journal of Chemistry 2019, 9(3), 236-248.

21-A. Dandia, S. L. Gupta, Sudheer, M. A. Quraishi, J. Mater. Environ. Sci., 2012, 3, 993-1000.

22-H. ZARROK, H. OUDDA, A. ZARROUK, R. SALGHI, B. HAMMOUTI, M. EBN TOUHAMI, S. S. AL-DEYAB, Gazi University Journal of Science, 2013, 26, 21-29.

23-H. K. Dhaef; A. H. Alaa, K. A. Hussain, Preparation, Characterization of Surfactants and study of Their corrosion Inhibitors for CarbonSteel in acidic media. basrah journal of science 2015, 33 (1C), 25-40.

24-A. Döner, E. A. Şahin, G. Kardaş, O. Serindağ, Corros. Sci. 2013, 66, 278-284.

25-S. A. El Haleem, S. A. El Wanees, E. A. El Aal, A. Farouk, Factors affecting the corrosion behaviour of aluminium in acid solutions. I. Nitrogen and/or sulphur-containing organic compounds as corrosion inhibitors for $\mathrm{Al}$ in $\mathrm{HCl}$ solutions. Corros. Sci. 2013, 68, 1-13.

26-O. Radovici, In Proceedings of the 2nd European Symposium on Corrosion Inhibitors, Ferrara, Italy, 1965; p 178.

27-S. S. Al-Juaid, Mono azo dyes compounds as corrosion inhibitors for dissolution of aluminium in sodium hydroxide solutions. Portugaliae Electrochimica Acta 2007, 25 (3), 363-373.

28-M. A. Amin, M. M. Ibrahim, Corrosion and corrosion control of mild steel in concentrated H2SO4 solutions by a newly synthesized glycine derivative. Corros. Sci. 2011, 53 (3), 873-885.

29-S. M. A. Hosseini, A. Azimi, I. Sheikhshoaei and M. Salari, Journal of Iranian Chemical Society, 7, 799-806 (2010).

30-30. E. A. Noor and A. H. Al. Moubaraki, Materials chemistry and physics, 110,145-154 (2008).

31-M. Elachouir. M. S. Hajji, M. Salem, S. Kertit, J. Aride, R. Coudert and E. Essassi, Corrosion, 1996, 52, 103.

32-Savitri. B. V and Mayanna . S, Indian Journal of Chemical Technology, 1996, 3, 3, 256.

33-C. M. Goulart, A. Esteves-Souza, C. A. Martinez-Huitle, C. J. F. Rodrigues, M. A. M. Maciel, A. Echevarria, Experimental and theoretical evaluation of semicarbazones and thiosemicarbazones as organic corrosion inhibitors. Corros. Sci., 2013, 67, 281-291.

34- A. Khamis, M. Saleh, M. Awad, Synergistic inhibitory effect of cetylpyridinium chloride and other halides on the corrosion of mild steel in 0.5 M H2SO4. Corros. Sci., 2013, 66, 343-349.

35-A. Khadraoui, A. Khelifa, Ethanolic extract of Ruta chalepensis as an eco-friendly inhibitor of acid corrosion of steel. Res. Chem. Intermed., 2013, 39 (9), 3937-3948. 
Table 6. Effect of (T1) on the Dissolution Mild-steel in 0.5M HCl.

\begin{tabular}{|c|c|c|c|c|c|c|c|c|c|c|c|c|c|c|c|c|}
\hline Time & \multicolumn{4}{|c|}{60} & \multicolumn{4}{|c|}{120} & \multicolumn{4}{|c|}{180} & \multicolumn{4}{|c|}{240} \\
\hline $\begin{array}{l}\text { Conc } \\
\text { (M) }\end{array}$ & $\begin{array}{l}\text { Wt- } \\
\text { loss } \\
\text { gm }\end{array}$ & $\begin{array}{c}\text { Rcorr., } \\
\text { gm.cm }{ }^{-2} \cdot \min ^{-1}\end{array}$ & $\mathrm{IE} \%$ & $\Theta$ & $\begin{array}{l}\text { Wt- } \\
\text { loss } \\
\text { gm }\end{array}$ & $\begin{array}{c}\text { Rcorr } \\
\mathrm{gm} . \mathrm{cm}^{-2} \cdot \mathrm{min}^{-1}\end{array}$ & IE\% & $\Theta$ & $\begin{array}{l}\text { Wt- } \\
\text { loss } \\
\text { gm }\end{array}$ & $\begin{array}{c}\text { Rcorr } \\
\text { gm.cm }{ }^{-2} \cdot \min ^{-1}\end{array}$ & IE\% & $\Theta$ & $\begin{array}{l}\text { Wt- } \\
\text { loss } \\
\text { Gm }\end{array}$ & $\begin{array}{c}\text { Rcorr } \\
\text { gm.cm }{ }^{-2} \cdot \min ^{-1}\end{array}$ & $\mathrm{IE}^{\%} \%$ & $\Theta$ \\
\hline 0.00 & 0.0138 & $81.32 \times 10^{-9}$ & - & - & 0.0187 & $91.38 \times 10^{-9}$ & - & - & 0.0252 & $10.17 \times 10^{-6-6}$ & - & - & 0.0299 & $15.01 \times 10^{-6}$ & - & - \\
\hline $1 \times 10^{-6}$ & 0.0027 & $29.37 \times 10^{-8}$ & 80.44 & 0.4160 & 0.8044 & $15.23 \times 10^{-8}$ & 85.03 & 0.8503 & 0.0018 & $65.27 \times 10^{-8}$ & 90.38 & 0.9038 & 0.0026 & $.70 .71 \times 10^{-8}$ & 91.97 & 0.9197 \\
\hline $1 \times 10^{-5}$ & 0.0025 & $27.19 \times 10^{-8}$ & 81.89 & 0.4722 & 0.8189 & $11.42 \times 10^{-9}$ & 88.78 & 0.8878 & 0.0022 & $79.77 \times 10^{-8}$ & 91.27 & 0.9127 & 0.0019 & $10^{-8} \times 51.67$ & 93.38 & 0.9338 \\
\hline $1 \times 10^{-4}$ & 0.014 & $15.23 \times 10^{-\frac{8}{8}}$ & 89.86 & 0.7777 & 0.8986 & $97.91 \times 10^{-8}$ & 90.38 & 0.9038 & 0.0019 & $68.90 \times 10^{-8}$ & 92.47 & 09247. & 0.0017 & $46.23 \times 10^{-8}$ & 94.32 & 0.9432 \\
\hline
\end{tabular}


Table 7. Effect of (T4) on the Dissolution Mild - steel in 0.5M HCl.

\begin{tabular}{|c|c|c|c|c|c|c|c|c|c|c|c|c|c|c|c|c|}
\hline Time & \multicolumn{4}{|c|}{60} & \multicolumn{4}{|c|}{120} & \multicolumn{4}{|c|}{180} & \multicolumn{4}{|c|}{240} \\
\hline $\begin{array}{l}\text { Conc } \\
\text { (M) }\end{array}$ & $\begin{array}{l}\text { Wt- } \\
\text { loss } \\
\text { gm }\end{array}$ & $\begin{array}{c}\text { Rcorr } \\
\mathrm{gm} . \mathrm{cm}^{-2} \cdot \mathrm{min}^{-1}\end{array}$ & IE\% & $\Theta$ & $\begin{array}{l}\text { Wt- } \\
\text { loss } \\
\text { gm }\end{array}$ & $\begin{array}{c}\text { Rcorr } \\
\mathrm{gm} \cdot \mathrm{cm}^{-2} \cdot \mathrm{min}^{-1}\end{array}$ & $\mathrm{IE}^{\%}$ & $\Theta$ & $\begin{array}{l}\text { Wt- } \\
\text { loss } \\
\text { gm }\end{array}$ & $\begin{array}{c}\text { Rcorr } \\
\mathrm{gm} . \mathrm{cm}^{-2} \cdot \mathrm{min}^{-1}\end{array}$ & $\mathrm{IE} \%$ & $\Theta$ & $\begin{array}{l}\text { Wt- } \\
\text { loss } \\
\text { Gm }\end{array}$ & $\begin{array}{c}\text { Rcorr } \\
\mathrm{gm} . \mathrm{cm}^{-2} \cdot \mathrm{min}^{-1}\end{array}$ & $\mathrm{IE}^{\%} \%$ & $\Theta$ \\
\hline 0.00 & 0.0138 & $81.32 \times 10^{-8}$ & - & - & 0.0187 & $91.38 \times 10^{-8}$ & - & - & 0.0252 & $10.17 \times 10^{-28}$ & - & - & 0.0299 & $15.01 \times 10^{-6}$ & - & - \\
\hline $1 \times 10^{-6}$ & 0.0028 & $30.46 \times 10^{-8}$ & 79.72 & 0.7972 & 0.0037 & $20.12 \times 10^{-8}$ & 80.22 & 0.8022 & 0.0044 & $15.95 \times 10^{-8}$ & 82.54 & 0.8224 & 0.0048 & $13.05 \times 10^{-8}$ & 83.95 & 0.8395 \\
\hline $1 \times 10^{-5}$ & 0.0026 & $28.28 \times 10^{-8}$ & 81.16 & 0.8116 & 0.0033 & $17.95 \times 10^{-8}$ & 82.36 & 0.8236 & 0.0042 & $15.23 \times 10^{-8}$ & 83.34 & 0.8334 & 0.0043 & $10^{-7} \times 11.69$ & 85.62 & 0.8562 \\
\hline $1 \times 10^{-4}$ & 0.0024 & $30.46 \times 10^{-\frac{8}{8}}$ & 82.61 & 0.8261 & 0.0031 & $20.12 \times 10^{-2}$ & 83.43 & 0.8343 & 0.0040 & $15.95 \times 10^{-8}$ & 84.13 & 0.8413 & 0.0025 & $13.05 \times 10^{-2}$ & 91.64 & 0.9164 \\
\hline
\end{tabular}


Table 8. Effect of (T6) on the Dissolution Mild - steel in 0.5M HCl.

\begin{tabular}{|c|c|c|c|c|c|c|c|c|c|c|c|c|c|c|c|c|}
\hline $\begin{array}{l}\text { Time } \\
\text { (Min.) }\end{array}$ & \multicolumn{4}{|c|}{60} & \multicolumn{4}{|c|}{120} & \multicolumn{4}{|c|}{180} & \multicolumn{4}{|c|}{240} \\
\hline $\begin{array}{l}\text { Conc } \\
\text { (M) }\end{array}$ & $\begin{array}{l}\text { Wt- } \\
\text { loss } \\
\text { gm }\end{array}$ & $\begin{array}{c}\text { Rcorr } \\
\text { gm.cm }{ }^{-2} \cdot \mathrm{min}^{-1}\end{array}$ & $\mathrm{IE}^{\circ} \%$ & $\Theta$ & $\begin{array}{l}\text { Wt- } \\
\text { loss } \\
\text { gm }\end{array}$ & $\begin{array}{c}\text { Rcorr } \\
\mathrm{gm} \cdot \mathrm{cm}^{-2} \cdot \mathrm{min}^{-1}\end{array}$ & $\mathrm{IE}^{\mathrm{P} \%}$ & $\Theta$ & $\begin{array}{l}\text { Wt- } \\
\text { loss } \\
\text { gm }\end{array}$ & $\begin{array}{c}\text { Rcorr } \\
\mathrm{gm} . \mathrm{cm}^{-2} \cdot \mathrm{min}^{-1}\end{array}$ & $\mathrm{IE}^{\circ} \%$ & $\begin{array}{l}\text { Conc } \\
\text { (M) }\end{array}$ & $\begin{array}{l}\text { Wt- } \\
\text { loss } \\
\text { gm }\end{array}$ & $\begin{array}{c}\text { Rcorr } \\
\mathrm{gm} . \mathrm{cm}^{-2} \cdot \mathrm{min}^{-1}\end{array}$ & $\mathrm{IE}^{\mathscr{\%} \%}$ & $\Theta$ \\
\hline 0.00 & 0.0138 & $81.32 \times 10^{-9}$ & - & - & 0.0187 & $91.38 \times 10^{-9}$ & - & - & 0.0252 & $10.17 \times 10^{-6}$ & - & - & 0.0299 & $15.01 \times 10^{-6}$ & - & - \\
\hline $1 \times 10^{-6}$ & 0.0050 & $54.39 \times 10^{-8}$ & 63.77 & 0.6377 & 0.0060 & $32.63 \times 10^{-8}$ & 67.92 & 0.6792 & 0.0061 & $24.82 \times 10^{-8}$ & 75.79 & 0.7579 & 0.0053 & $14.41 \times 10^{-9}$ & 82.28 & 0.8228 \\
\hline $1 \times 10^{-5}$ & 0.0045 & $48.95 \times 10^{-9}$ & 67.39 & 0.6739 & 0.0044 & $23.39 \times 10^{-9}$ & 76.48 & 0.7648 & 0.0052 & $18.85 \times 10^{-9}$ & 79.37 & 0.7937 & 0.0045 & $10^{-9} 12.23 \times$ & 84.95 & 0.8495 \\
\hline $1 \times 10^{-4}$ & 0.0031 & $33.72 \times 10^{-9}$ & 77.54 & 0.7754 & 0.0037 & $20.12 \times 10^{-8}$ & 80.22 & 0.8022 & 0.0035 & $12.69 \times 10^{-9}$ & 86.12 & 0.8612 & 0.0035 & $95.19 \times 10^{-2}$ & 88.29 & 0.8829 \\
\hline
\end{tabular}


Table 9. Effect of (T8) on the Dissolution Mild - steel in 0.5M HCl.

\begin{tabular}{|c|c|c|c|c|c|c|c|c|c|c|c|c|c|c|c|c|}
\hline $\begin{array}{l}\text { Time } \\
\text { (Min.) }\end{array}$ & \multicolumn{4}{|c|}{60} & \multicolumn{4}{|c|}{120} & \multicolumn{4}{|c|}{180} & \multicolumn{4}{|c|}{240} \\
\hline $\begin{array}{l}\text { Conc } \\
\text { (M) }\end{array}$ & $\begin{array}{l}\text { Wt- } \\
\text { loss } \\
\text { gm }\end{array}$ & $\begin{array}{c}\text { Rcorr } \\
\mathrm{gm} \cdot \mathrm{cm}^{-2} \cdot \mathrm{min}^{-1}\end{array}$ & $\mathrm{IE}^{\%} \%$ & $\Theta$ & $\begin{array}{l}\text { Wt- } \\
\text { loss } \\
\text { gm }\end{array}$ & $\begin{array}{c}\text { Rcorr } \\
\mathrm{gm} \cdot \mathrm{cm}^{-2} \cdot \mathrm{min}^{-1}\end{array}$ & $\mathrm{IE}^{\circ} \%$ & $\Theta$ & $\begin{array}{l}\text { Wt- } \\
\text { loss } \\
\text { gm }\end{array}$ & $\begin{array}{c}\text { Rcorr } \\
\mathrm{gm} \cdot \mathrm{cm}^{-2} \cdot \mathrm{min}^{-1}\end{array}$ & $\mathrm{IE}^{\circ} \%$ & $\Theta$ & $\begin{array}{l}\text { Wt- } \\
\text { loss } \\
\text { gm }\end{array}$ & $\begin{array}{c}\text { Rcorr } \\
\mathrm{gm} \cdot \mathrm{cm}^{-2} \cdot \mathrm{min}^{-1}\end{array}$ & $\mathrm{IE}^{\circ} \%$ & $\Theta$ \\
\hline 0.00 & 0.0138 & $81.32 \times 10^{-9}$ & - & - & 0.0187 & $91.38 \times 10^{-9}$ & - & - & 0.0252 & $10.17 \times 10^{-6}$ & - & - & 0.0299 & $15.01 \times 10^{-6}$ & - & - \\
\hline $1 \times 10^{-6}$ & 0.0045 & $48.95 \times 10^{-\frac{7}{8}}$ & 67.39 & 0.6739 & 0.0055 & $29.91 \times 10^{-\frac{7}{8}}$ & 70.59 & 0.7059 & 0.0070 & $25.38 \times 10^{-9}$ & 72.23 & 0.7223 & 0.0060 & $16.31 \times 10^{-\frac{7}{8}}$ & 79.94 & 0.7994 \\
\hline $1 \times 10^{-5}$ & 0.0041 & $44.60 \times 10^{-\frac{7}{8}}$ & 70.28 & 0.7028 & 0.0052 & $28.28 \times 10^{-8}$ & 72.19 & 0.7219 & 0.0061 & $22.12 \times 10^{-9}$ & 75.79 & 0.7579 & 0.0054 & $10^{-5} \times 14.68$ & 81.94 & 0.8194 \\
\hline $1 \times 10^{-4}$ & 0.0035 & $38.07 \times 10^{-9}$ & 74.64 & 0.7464 & 0.0042 & $22.84 \times 10^{-7}$ & 77.55 & 0.7755 & 0.0051 & $18.49 \times 10^{-8}$ & 79.77 & 0.7977 & 0.0052 & $14.14 \times 10^{-8}$ & 82.61 & 0.8261 \\
\hline
\end{tabular}


Table 10. Effect of (T9) on the Dissolution Mild - steel in 0.5M HCl.

\begin{tabular}{|c|c|c|c|c|c|c|c|c|c|c|c|c|c|c|c|c|}
\hline $\begin{array}{l}\text { Time } \\
\text { (Min.) }\end{array}$ & \multicolumn{4}{|c|}{60} & \multicolumn{4}{|c|}{120} & \multicolumn{4}{|c|}{180} & \multicolumn{4}{|c|}{240} \\
\hline $\begin{array}{l}\text { Conc } \\
\text { (M) }\end{array}$ & $\begin{array}{l}\text { Wt- } \\
\text { loss } \\
\text { gm }\end{array}$ & $\begin{array}{l}\text { Rcorr } \\
\mathrm{gm} \cdot \mathrm{cm}^{-2} \cdot \mathrm{min}^{-1}\end{array}$ & $\mathrm{IE}^{\circ} \%$ & $\Theta$ & $\begin{array}{l}\text { Wt- } \\
\text { loss } \\
\text { gm }\end{array}$ & $\begin{array}{l}\text { Rcorr } \\
\mathrm{gm} \cdot \mathrm{cm}^{-2} \cdot \mathrm{min}^{-1}\end{array}$ & $\mathrm{IE}^{\mathrm{O} \%}$ & $\Theta$ & $\begin{array}{l}\text { Wt- } \\
\text { loss } \\
\text { gm }\end{array}$ & $\begin{array}{c}\text { Rcorr } \\
\text { gm. } \mathrm{cm}^{-2} \cdot \mathrm{min}^{-1}\end{array}$ & $\mathrm{IE}^{\circ} \%$ & $\Theta$ & $\begin{array}{l}\text { Wt- } \\
\text { loss } \\
\text { gm }\end{array}$ & $\begin{array}{c}\text { Rcorr } \\
\mathrm{gm} \cdot \mathrm{cm}^{-2} \cdot \mathrm{min}^{-1}\end{array}$ & $\mathrm{IE}^{\mathrm{D} \%}$ & $\Theta$ \\
\hline 0.00 & 0.0138 & $81.32 \times 10^{-9}$ & - & - & 0.0187 & $91.38 \times 10^{-9}$ & - & - & 0.0252 & $10.17 \times 10^{-6}$ & - & - & 0.0299 & $15.01 \times 10^{-6}$ & - & - \\
\hline $1 \times 10^{-6}$ & 0.0052 & $56.57 \times 10^{-8}$ & 62.31 & 0.6231 & 0.0047 & $25.56 \times 10^{-8}$ & 74.87 & 0.7487 & 0.0054 & $19.58 \times 10^{-98}$ & 78.58 & 0.7858 & 0.0062 & $16.86 \times 10^{-8}$ & 79.26 & 0.7926 \\
\hline $1 \times 10^{-5}$ & 0.0040 & $43.51 \times 10^{-9}$ & 71.02 & 0.7102 & 0.0046 & $25.02 \times 10^{-9}$ & 75.41 & 0.7541 & 0.0052 & $18.85 \times 10^{-9}$ & 79.37 & 0.7937 & 0.0058 & $10^{-7} \times 15.77$ & 80.61 & 0.8061 \\
\hline $1 \times 10^{-4}$ & 0.0036 & $39.16 \times 10^{-9}$ & 73.92 & 0.7392 & 0.0044 & $23.93 \times 10^{-9}$ & 76.48 & 0.7648 & 0.0050 & $18.13 \times 10^{-9}$ & 80.16 & 0.8016 & 0.0055 & $14.95 \times 10^{-8}$ & 81.61 & 0.8161 \\
\hline
\end{tabular}

Table 11. Effect of (T1, T4, T6, T8 and T9) on the Dissolution Mild - steel in 0.5M HCl in the Different Temperature. 


\begin{tabular}{|c|c|c|c|c|c|c|c|c|c|c|c|c|c|}
\hline \multirow{2}{*}{ Comp., } & Temp. ${ }^{\circ} \mathrm{C}$ & \multicolumn{4}{|c|}{25} & \multicolumn{4}{|c|}{35} & \multicolumn{4}{|c|}{45} \\
\hline & $\begin{array}{l}\text { Conc. } \\
\text { (M) }\end{array}$ & $\begin{array}{l}\text { Wt.- } \\
\text { loss } \\
\text { gm }\end{array}$ & $\begin{array}{c}\mathrm{R} \text { corr. } \\
\mathrm{gm} \cdot \mathrm{cm}^{-2} \cdot \mathrm{min}^{-1}\end{array}$ & IE\% & $\Theta$ & $\begin{array}{l}\text { Wt- } \\
\text { loss } \\
\text { Gm }\end{array}$ & $\begin{array}{c}\text { Rcorr } \\
\mathrm{gm} \cdot \mathrm{cm}^{-2} \cdot \mathrm{min}^{-1}\end{array}$ & $\mathrm{IE}^{\%} \%$ & $\Theta$ & $\begin{array}{l}\text { Wt- } \\
\text { loss } \\
\text { gm }\end{array}$ & $\begin{array}{c}\text { Rcorr } \\
\mathrm{gm} \cdot \mathrm{cm}^{-2} \cdot \mathrm{min}^{-1}\end{array}$ & $\mathrm{IE} \%$ & $\Theta$ \\
\hline $\mathrm{HCl}$ & 0.00 & 0.0299 & $15.01 \times 10^{-6}$ & - & - & 0.0584 & $15.88 \times 10^{-6}$ & - & - & 0.0710 & $19.31 \times 10^{-6}$ & - & - \\
\hline $\mathrm{T} 1$ & $1 \times 10^{-4}$ & 0.0017 & $46.23 \times 10^{-8}$ & 94.32 & 0.9432 & 0.0103 & $28.01 \times 10^{-8}$ & 83.36 & 0.8236 & 0.0198 & $53.85 \times 10^{-9}$ & 72.11 & 0.7211 \\
\hline $\mathrm{T} 4$ & $1 \times 10^{-4}$ & 0.0025 & $13.05 \times 10^{-8}$ & 91.64 & 0.9164 & 0.0116 & $31.54 \times 10^{-8}$ & 80.13 & 0.8013 & 0.0172 & $46.77 \times 10^{-9}$ & 75.77 & 0.7577 \\
\hline $\mathrm{T} 6$ & $1 \times 10^{-4}$ & 0.0035 & $95.19 \times 10^{-8}$ & 88.29 & 0.8829 & 0.0198 & $53.85 \times 10^{-8}$ & 66.1 & 0.661 & 0.0272 & $73.97 \times 10^{-9}$ & 61.7 & 0.617 \\
\hline $\mathrm{T} 8$ & $1 \times 10^{-4}$ & 0.0052 & $14.14 \times 10^{-8}$ & 82.61 & 0.8261 & 0.0182 & $49.49 \times 10^{-9}$ & 68.48 & 0.6848 & 0.0339 & $92.19 \times 10^{-9}$ & 52.26 & 0.5226 \\
\hline T9 & $1 \times 10^{-4}$ & 0,0055 & $14.95 \times 10^{-9}$ & 81.61 & 0.8161 & 0.0172 & $46.77 \times 10^{-8}$ & 70.55 & 0.7055 & 0.0262 & $71.25 \times 10^{-9}$ & 63.1 & 0.631 \\
\hline
\end{tabular}

